\title{
Biografía
}

\section{Dr. Karl Hoffmann Brehmer}

El nombre del médico alemán Karl Hoffmann Brehmer está indisolublemente unido a la historia de Costa Rica, patria que hizo suya a pesar de haber nacido lejos. Y la hizo suya demostrando genuino amor filial en los frentes de batalla de Guanacaste y Nicaragua, donde se afianzarían la soberanía y la libertad de nuestro país y de toda Centroamérica.

Allá, Hoffmann debió empuñar el fusil cuando las circunstancias lo demandaron, pero, sobre todo, desplegó su valentía y sapiencia de médico para afrontar una situación de dimensiones descomunales. Sus aportes como cirujano mayor del Ejército Expedicionario -junto con cuatro colegas $\mathrm{y}$ un ayudante- contribuyeron a anular la amenaza del esclavismo, encarnado en la doctrina del Destino Manifiesto $\mathrm{y}$ en las armas del ejército filibustero de William Walker.

Aunque la cifra de muertos en la batalla de Rivas está en discusión, históricamente se la ha establecido en unos 500 combatientes de nuestras filas (jen menos de 24 horas de combate!), pero también hubo unos 300 heridos. Sin camas ni medicamentos suficientes, 270 de ellos fueron albergados en el "hospital de sangre", improvisado el 11 de abril por la tarde en la casa de Maliaño. Según consta en la detallada lista de heridos preparada por él, a siete de ellos hubo que hacerles amputaciones, en condiciones de higiene inadecuadas.

Nacido el 7 de diciembre de 1823 en Stettin, Prusia, en 1846 Hoffmann se había graduado como médico en la Universidad de Berlín. Aparte de su interés hacia las ciencias naturales, a las que dedicó buena parte de su tiempo, ejerció como médico en varios hospitales de Berlín durante 1848 y 1849, y hasta tuvo la oportunidad de tratar a enfermos de cólera morbus. Esta experiencia previa sería realmente providencial para nuestra patria, pues pocos días después de la batalla de Rivas se manifestaría el primer caso de cólera.

Imputados los "vapores miasmáticos" de Rivas como su causa, por parte del presidente don Juan Rafael Mora y de los médicos -cuando se desconocía que su agente causal era la bacteria Vibrio cholerae-, se ordenó la repatriación de nuestras tropas. Bajo el ardiente sol de abril, el retorno fue espantoso. Sufriendo incontenibles diarreas que causaban postración en pocas horas o días, a la vera de los caminos fueron quedando los cadáveres, en fosas improvisadas. Y, con la llegada del inóculo a los sitios más poblados, la epidemia creció de manera exponencial, hasta causar unas 10.000 muertes, equivalentes al $8-10 \%$ de la población de entonces.
Pero, en medio del pavor y la desesperación colectivos, emergió serena y sabia la voz de Hoffmann. Presto y oportuno, publicó dos boletines con consejos de naturaleza preventiva, como evitar frutas y bebidas fermentadas, consumir reconstituyentes y mantener una actitud anímica positiva, así como consumir un preparado de gotas amargas vertidas en coñac o vino fino, denominado por él "medicina anticolérica", "mixtura tónica" o "esencia tónica".

Este era de uso obligatorio para los sepultureros que, en carretas, trasladaban decenas de cuerpos apilados y los depositaban en fosas comunes en los cementerios. Asimismo, tuvo tanta acogida entre la ciudadanía, que las autoridades, bastante preocupadas, debieron advertir: "muchos son los que se medicinan en sana salud y no pocos los que hacen un uso pernicioso de las gotas amargas y el coñac". Puesto que hoy se sabe que este tipo de alcoholes y las bebidas ácidas matan al bacilo de manera casi instantánea, es posible que la

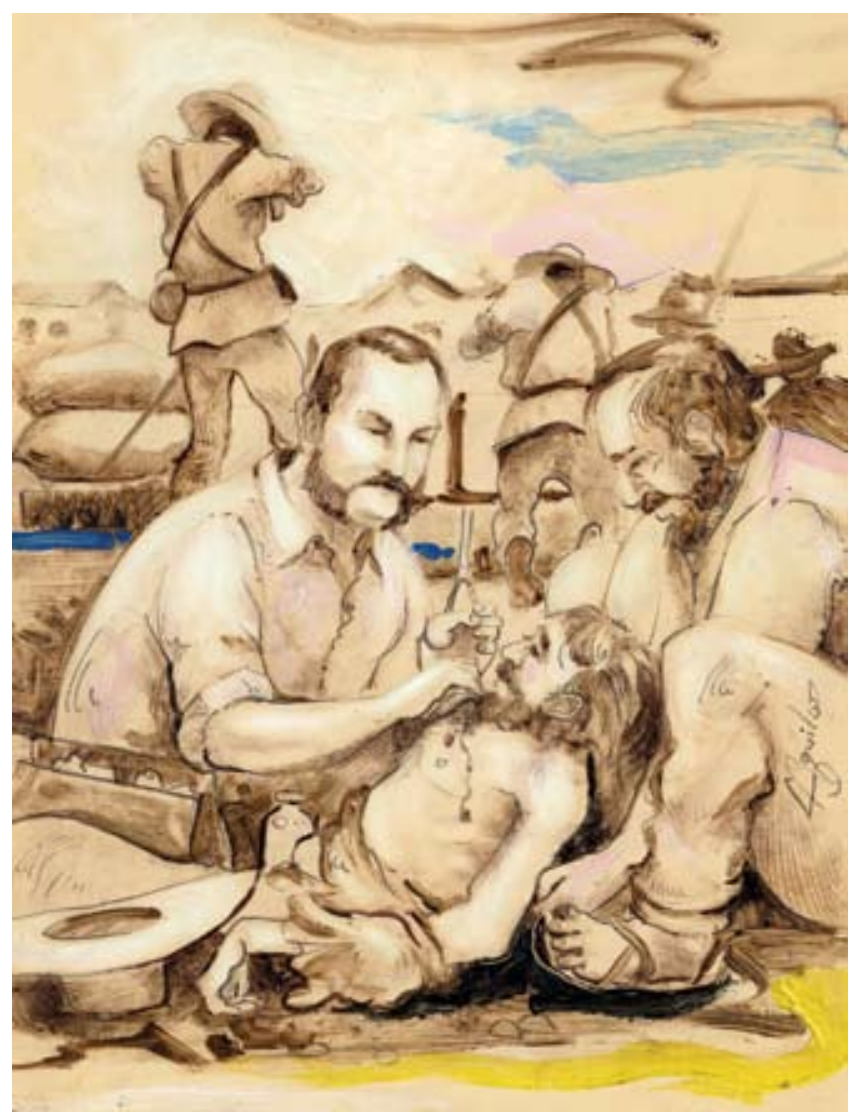

El Dr. Karl Hoffmann cumpliendo su labor humanitaria. Dibujo: Carlos Aguilar Durán. 
oportuna ingestión del preparado evitara el desarrollo de la enfermedad y, con ello, que la epidemia causara estragos aún mayores.

Superada la etapa de la epidemia y reanudada la guerra con las definitorias batallas del río San Juan, Hoffmann se ausentaría de la vida pública. También debió cancelar sus giras a nuestras montañas, que fue uno de los motivos por los que se trasladó a Costa Rica, y que justificó la carta de recomendación que, en 1853, su mentor, el sabio Alexander von Humboldt -el gran explorador de América-, remitiera al presidente Mora. Además, por su probada capacidad profesional, compromiso y estrecha relación con el Gobierno, le correspondía asumir la dirección del Hospital San Juan de Dios, pero quien lo haría sería el estadounidense Santiago Hogan.

Todo esto obedeció al serio deterioro de su salud -como resultado de la incesante actividad desplegada en los meses previos-, debido a un problema de la médula y del intestino mayor, según constaría en el acta de defunción. Sus dedos fueron endureciéndose y perdiendo movilidad, lo que le impedía ejercer como médico, de manera que el Gobierno le otorgó una pensión. Buscando un clima más cálido, a inicios de 1859 partía con su esposa hacia Puntarenas, pero pronto ella moriría de tifoidea. Severamente deprimido, él expiró el 11 de mayo, a los 35 años de edad.

Sus restos permanecieron casi abandonados en el cementerio de Esparza durante 70 años, pero en 1929 se les exhumó y trasladó a San José y, con honores de General de Brigada, se les depositó en el Cementerio General, donde hoy reposan junto a los de su esposa Emilia.

Como tributo a su extraordinaria labor humanitaria y cívica, en 2008 el auditorio del Hospital San Rafael, en Alajuela, fue bautizado con su nombre.

\section{Luko Hilje Quirós}

Biólogo. Profesor Emérito del Centro Agronómico

Tropical de Investigación y Enseñanza (CATIE).

luko@ice.co.cr 